Duncan Webster B.A. (Hon), B.Sc., M.A. Dalhousie Medical School, Class of 2001

$\mathrm{T}$ he following paper is based on a discussion with two traditional healers from the Mi'kmaq reserve of Eskasoni in Cape Breton. Medicinal plants are at the centre of the discussion, how literature search, aspects of which there were a variety of topics. The discussion was followed with a physicians and health care workers were also of great vated into the body of the paper. A variety of without a final conclusion, analogous to a circle that value through ongoing dialogue. This paper is

\section{METAPHYSICS - THE ROOT}

On the banks, on both sides of the river, there will grow all kinds of trees for food. Their leaves will not wither nor their fruit fail, but they will bear fresh fruit every month, because the water for them flows from the sanctuary. Their fruit will be for food and their leaves for healing.

-Ezekiel 47:12

Minutes after having packed up my tent, I found myself heading east from the shores of Lake Bras d'Or. Though it seemed early, the sun had already travelled a great distance along the vertical axis and its brass rays cut through the quiet air of Eskasoni. As the car wound its way through the largest reserve in Nova Scotia, I could actually hear the voices of children speaking their native tongue! Suddenly, there was the house I had been zeroing in on since I had left Halifax three days ago. I knocked at the door and was greeted by a Mi kmaq woman who did not appear to be older than fifty. This surprised me as I had been told that she was close to seventy years old. She was renowned throughout the region as one of the most knowledgeable herbal healers and I felt $a$ sense of great humility as I entered her home. There was a large pot on the stove and she offered me a cup of tea. The pot was full of simmering water and lange roots which she explained were wabegpagosi. Pagosi is a local plant also known as cow parsnip and commonly used as a general tonic. As we sat at

Address correspondence to:

Duncan Webster, B.A. (Hon), B.Sc., M.A

965 McLean St., Apt. 1, Halifax, Nova Scotia, B3H 2 V2. her table, the conversation was fluid, but often strained by difficulty with language. Mi'kmaq was her first language and her English was beautiful and broken.

For the naturalist and the traditional healer, Nature is powerful beyond the logic of mechanics. "Particular natural facts are symbols of particular spiritual facts, and $\mathrm{Na}$ ture is the symbol of spirit [1]." Furthermore, Nature is felt to be personal and alive. The Seneca prophet, Handsome Lake was told in a vision:
You don't realize that the Creator planted medicine for your relations to use. It grows all over the world. Do you hear the medicine spirits singing?

In their song they are saying, "we are all over the land. We are ready to help if the people will come to us for help [2].

This intimate relationship is what this Mi'kmaq woman was trying to impress upon me. As she spoke, I realized that her views were logical. It was just that they began with vastly different axiomatic inferences. She was a holdout from an ancient time, upholding a dying tradition. Some claim that such traditional healers are the antagonist of the modern physician. As Illich explained, "when doctors first set up shop outside the temples in Greece, India, and China, they ceased to be medicine men. When they claimed rational power over sickness, society lost the sense of complex personage and his integrated healing which the sorcerer-shaman had provided [3]." I wondered about the potential for reconciliation between the poet and the priest. 


\section{POLITICS}

A short while passed and her son, Japhy, entered from outside. He was a young man of about thirty years and eager to receive the cultural heritage his mother was willing to pass on to him. He seemed skeptical of my intentions as we discussed the philosophy of medicinal plants and the intricate connections that exist between the plant world and the human experience. He spoke of revitalization among the First Nations people, a natural Way and the unfortunate inabilit of the scientific community to grasp this understanding. He emphasized the problems inherent in a monopolized system of health management based on applied engineering as well as the promotion of medical consumerism. An alternate approach was offered, yet it seemed so foreign. Thus Emerson's words resonated:

Nature is a discipline of the understanding of intellectual truths. Our dealing with sensible objects is a constant exercise in the necessary lessons of difference, of likeness, of order, of being and seeming, of progressive arrangement; of ascent from particular to general; of combination to one end of manifold forces [4]

Many of Japhy's concerns regarding contemporary health care have been expressed systematically by Ivan Illich. acclaimed critic of industrial society. In his 1976 effort, Limits to Medicine, Illich critiques the disabling effects of institutionalized health care and the professional control that has come to monopolize the way that society cares for itself. This description of medical colonization by the more affluent serves to defend the views Japhy expressed in Eskasoni. Illich discusses this "expropriation of health" and claims three levels of iatrogenesis: clinical, social, and cultural. It is at the level of social iatrogenesis, where "the environment is deprived of those conditions that endow individuals, families, and neighbourhoods with control over their own internal states and milieu [5]," that Illich touches on the conflict facing traditional healers and naturalists who treat with medicinal plants. Traditional medicine, Illich explains, "is losing its makeshift, semi-independent, grassroots character and is being integrated into a unitary health-care technocracy [6]." As a result, the traditional healer faces loss of autonomy, loss of control over resources, and the potential loss of an underlying tradition. Thus many aspects of medicine are taken from the hands of the people and set adrift in the institutionalized tides of the
market economy.

History recently recorded this type of socially-structured iatrogenesis in the early 1970 s when a medical doctor then president of Chile Dr. Salvador Allende, along with his ruling socialist government began to reroute their national health care system. The focus appears to have been on decentralizing the system, rebuilding a social network of health clinics, and focusing on primary and secondary care. This government also attempted to revive a programme aimed at reducing the national pharmacopoeia to a few dozen items, Many were not pleased with the relative loss of medical technology and the subsequent decline of medical standards at highly specialized medical centres. Furthermore, many so phisticated pharmaceutical products could no longer be pre scribed. As one doctor at the time described the situation "Chilean medicine started to recede to the medical standard of a generation earlier" [7]. However, as is generally the case it seems that it was also a matter of perspective as anothe physician described the Chilean National Health Service of that time as "a model of health-care delivery for the less-privi leged" and claimed that "during the Allende administration there was a significant improvement of the health status of
Chilean people [8]"

Regardless of the rhetoric, it is a fact that the pharmacopoeia was reduced. This is pause for consideration when one considers the size of the present CPS as well as provincial and hospital formularies. The reduction of the pharmacopoeia down to a few dozen items sounds very extreme when compared to the World Health Organization (WHO) List of Essential Drugs [9]. This list of the "essentials" contains twenty-seven categories alone and up to eight sub-sections in any given category with only a few drugs listed more than once. Certainly the number of pharmaceutical agents has grown since the early 1970 s, however, this action of Allende and his ruling government, who felt obliged to reduce their national formulary down to such a limited number of pharmaceuticals, is defended by Illich who explains:

Opinions vary about the actual number of useful drugs: some experienced clinicians believe that less than two dozen basic drugs are all that will ever be desirable for 99 per cent of the total population; others, that up to four dozen items are optimal for 98 per cent [10].

This taken as true and valid, Allende's reform of the pharmacopoeia may be seen as legitimate and admirable However, such reform did not come without its price. On September 11, 1973, the Chilean military junta seized power in a coup that saw the murder not only of Dr. Salvador Allende himself, but of "many of the most outspoken proponents of a Chilean medical system based on community action rather than on drug imports and drug consumption [11]." Thus, the Chilean masses suffered the loss of control over internal states and the deprivation of the people's ability to effectively manage their own health care system.

\section{ECONOMY}

There is no doubt that there were a number of variables that drove this group of health care workers to reform the system, just as there were many factors that lead to the military coup. As armed conflict raged in Asia, and the Cold War simmered on the European front, political agendas in South America were driven by opposing ideologies. Also intricately tied into the local setting were global economies. Allende had critiqued the capitalist exploitation of illness by the pharmaceutical industry, comparing the prices of brandname drugs with their generic equivalents. Allende wrote in his La Realidad Medico-Social Chilena: 
Thus, for example, we find a drug with important action on infectious diseases, sulfanilamide, these different names and prices: Prontosil \$26.95, Gombardol \$20.80, Septazina \$21.60, Aseptil $\$ 18.00$, Intersil \$13.00, Acetilina \$6.65. All these products, which in the eyes of the public appear with different names, correspond, in reality, to the same medication which is sold in a similar container and which contains 20 tablets of 0.50 grams of sulfanilamide...Progress obtained in the output of national production has not yielded a sensible margin of well-being in the popular strata, because international capitalism - economic and financial master of the large centres of production - is interested only in producing to satisfy the demand of the market and no more. For the capitalist enterprise it is of no concern that there is a population of workers who live in deplorable conditions, who risk being consumed by diseases or who vegetate in obscurity [12].

Allende recognized that the industry was not providing for the Chilean people in an efficient matter. There was intentional confusion within the marketplace and in fact the market was draining the pockets of the nation to the point that many people were suffering. This was an important observation, for economy is vital to the prosperity of the individual as well as the greater community.

As Henry David Thoreau experienced in the 1800's, it is through economy that one is able to maintain the "necessaries of life." Economic feasibility for the masses living close to the land lies in simplicity and in the recognition of these true "necessaries." Thoreau clarified that these "be distributed under the several heads of Food, Shelter, Clothing, and Fuel [13]." This viable form of economics is also ackowledged by the First Nations traditionalists. In line with Thoreau, an elderly Mi'kmaq woman from the Gold River Mi'kmaq Reserve shared the theory of natural economy, stating "I was always told by my parents that Mother Nature provides for us all whether the need is for food, shelter or clothing" [14]. Though this may appear to be a leap of faith, it is also a view based on experience.

\section{EMPIRICISM}

The traditional method put forth in Eskasoni was systematic and had been passed on from generation to generation. In order to help illuminate the philosophy, a pencil and paper lay waiting on the kitchen table. With weathered hands, Japhy drew seven lines on the paper and explained that the medicinal plant could be divided into the following seven parts: root, stem, bark, leaves, flower, fruit, and seed. Each part has its own medicine.

There is no dispute over the fact that certain plants have medicinal value and that each part of the plant harbours its own chemistry. For example, the Mountain Ash, Sorbus sorbier, known to the Mi'kmaq as epsemosi, produces berries that are rich in both iron and Vitamin $\mathrm{C}$ and were thus important medicines for the treatment of scurvy. The leaves. on the other hand, foster highly poisonous cyanide compounds and therefore must be prepared with extreme caution although they have a very useful emetic property [15]. Such examples are multitudinous and medical science has benefited from these natural occurrences. Further examples may be found in the WHO List of Essential Drugs that includes natural compounds such as polysaccharides, nucleosides, antibodies, hormones, minerals, and raw elements, as well as bacterial and fungal metabolites and viral proteins. The various plants from which medicines embraced by the WHO essential list have been derived include Erythroxylon coca, Atropa belladonna, Datura stramonium, Papaver somniferum, Salix spp., Colchium autumnale, Cinchona spp., Cephaelis ipecocuanha. Cephaelis acuminata, Vinea rosea, Digitalis purpurea, Rauwolfia serpentina, Podophylum peltatum, Cassia acutifolia, Cassia angustifolia, Strychoros spp., Chondrodendron spp., Physostigma venenosum, and Thea sinensis. These are the plants that pertain specifically to essential medicines and the list of unessentials is exhaustive. To this day medical science continues to explore the pharmaceutical potential of the botanical gardens of the natural world and the number of available pharmaceuticals continues to grow.

Illich claims "the age of new drugs began with aspirin in 1899" [16]. Aspirin, derived from willow bark, is the initial drug of choice for treating the majority of articular and musculoskeletal disorders due to its antirheumatic properties. It also has analgesic, antipyretic, and anti-inflammatory properties. The active ingredient in willow bark is salicin, which on hydrolysis yields glucose and salicylic acid. It is fascinating to note that "the documented use of willow bark as a pain reliever dates back to the golden age of the Greek Empire, some 2400 years ago, at the same time that native people of North America were prescribing willow bark tea for fever and head ache" [17]. The active ingredient appears to have been close to discovery in 1763 when, in a letter to the president of the Royal Society, Reverend Edmund Stone described "success in treating fever with the powdered form of the bark of the willow" [18]. Yet is was not until 1827 that salicin was first discovered by Leroux [19].

Interestingly, in his letter to the Royal Society, Reverend Stone noted that "the bitterness of the bark of the willow was reminiscent of the taste of cinchona bark, the source of quinine" [20]. During the Victorian era, before the time of aspirin, there were very few natural medicines used at large. "Before [1899]," Illich writes, "besides opium, the only substances of wide application which would have passed tests for safety and effectiveness were smallpox vaccine, quinine for malaria, and ipecac for dysentery." However, this is odd since these were not the only medicines provided by nature that were known to be valuable medicinal sources at that time. Saint John's Wort, Hypericum perforatum L., serves as one example. Listed by Culpeper in his Herball published in 1653 , it is described as having a variety of applications. Among its many virtues, "made into an ointment, it opens obstructions, dissolves swellings, and closes up the lips of wounds" [21]. One source maintains that according to legends surrounding the herb, "it was espoused by Saint John of Jerusalem who is 
said to have used it in the time of the crusades as a battlefield balm for its abilities to clean and heal some terrible battle wounds" [22], thus gaining its present name. However, another source claims that "early healers collected it around St. John's Tide (June 24) and [thus] called it St. John's Wort. Regardless, of the derivations of its name, it has a long history of use among traditional healers and is now gaining acceptance within the scientific community as an antidepressant. In fact, in 1996, it had already "seized $50 \%$ of the German antidepressant market with over 20 million yearly consumers" [24]. The active ingredient is hypericin, and appears to act via inhibition of serotonin re-uptake. The question has been asked, "If it really works and is safe, then why is not a first-line treatment for mild to moderate depression in North America"[25]. For naturalist, this is a particularly poignant question in light of the fact the vast majority of psychotherapeutic drugs are synthetic. This is despite the fact that traditional healers throughout the world are known to use many medicinal plants with psychoactive and psychotherapeutic properties. Certainly these specific plants have a cultural context. However, there is a deeply rooted logic that underlies the traditional use of not only psyhoactive plants, but in fact the use of all medicinal plants. It is based on the concept of non-locality.

\section{LOGIC}

I sipped slowly on my tea as Japhy continued to provide insight into his traditional beliefs. He viewed the world as a spiritual biosphere in which both plants and animals were inter-connected. He looked at me with tired eyes and explained that people are as rooted to the land as plants. The two share in the same life process in which order and higher meaning prevail. It is through this order and interconnected existence that the essential medicines necessary for healing and balanced growth come into being. Thus these medicines are part of the land just as the people are a part of the land. It is only when the root is severred, that the people become like tumbleweed-isolated, seperate and unrelated. Even within the canon of scientific materialism, this is no longer a foreign concept. For example, physical experiments in quantum optics have shown that two distant events can influence each other faster than any signal could have traveled between them. [26]. The fact of such inter-relatedness between seemingly isolated systems is gaining new recognition. Within academia, nonlocality is presently receiving much attention and many feel quite free to recognize nonlocality as fact of nature and recognize the inferences which follow such as the existence of an undivided wholeness on the primary level in physical reality. It is a feature of the new physics which recognizes the single holistic totality of a quantum system regardless of the distance which may exist between particles. As Kafatos
and Nadueu claim:

If we can assume that our scientific world view plays a large role in conditioning our understanding of the character of self and world, nonlocality as a new fact of nature could be just as revolution- ary in these terms as the confirmation of the Copernican hypothesis in the 17th Century [27]

As a cosmological understanding this is the same as the oneness within nature that is recognized by the Aboriginal cosmology. It is concept which subverts the bias that the world is composed most fundamentally of individual objects and their nonrelational properties.

Thus one may consider the relationship that exists between plans and animals. Though perceived as sepatate and distinct entities, the two are parts of a greater whole- a common organic system. Traditional herbal medicine has at its root this mystical basis founded in the recognition of the interconnectedness of all creation. Humanity is not viewed as cut off or separated from the rest of nature, but rather is seen as a part of the Creation in which all things share in a non-localized existence. It is for this reason that since time immemorial, nature's pharmacy has provided medicine and nourishment for humanity through the curative virtues of the plant; for the two are part of one another. Despite our present infatuation with synthetic substance here in the West, Grassroots Healers insist that Nature and her Plant Kingdom already provide the greatest laboratory on earth. The intricacy of the processes and the organic creativity of Nature are viewed as so deep and complex that the Rasta bush doctor Kamba explains, "The operations of a single plant humble us and can be explained by only One[28]. One has intent and purpose and all parts are interconnected. It is not by chance that the plant can heal the human, rather it is due to the fact of nonlocality which makes the two part of, and made for, one another.

\section{ETHICS}

Japhy put down the pencil as I drank the last of my tea. I could not fully digest the thoughts that were racing through my mind. I sat and stared, not knowing how to express what seemed to be the logical consequence of his valid arguement. Suddenly my focus shifted as a dog ran by the window, barking and wagging its tail. A young child in rubber boots was chasing the dog and laughing. The child's expression was a sharp constrast to the somber look on.Japhy's face. He abruptly rose from his chair and left without any formal parting words. The fire of my mind snapped and crackled as if the dry timber had just been added to the blaze. I struggled as my thoughts began to focus on familiar concepts. On the one hand sat John Stuart Mill spouting his utilitarian ethic, claiming that the end justifies the means. He claimed that it is acceptable that the few suffer for the good of the many. I couldn't help but wonder about depth perception in light of posterity. In the other hand Emmanuel Kant stood defending a deontological ethic expressing the belief that every means is and end in itself. I wondered over this categorical imperative and huamnity's duty toward nature. As many claim that despotism is our right, others maintain the attitude of stewardship and cooperation. This is as true for the environment as it is for foreign policy, as perspective and value become synthesized. 
The medicinal value inherent in nature has been argued, as has nature's economic value. The political issue of impinging on a people's ability to manage their own health has also been discussed. Yet there is the further question of pollution and contamination of nature's medicinal resources which is of present concern in areas of Cape Breton such as Eskasoni and Membertou.

\section{ECOLOGY - THE SEED}

Science and technology have had a strained relationship with nature since their relatively recent birth. They have been the cause of vast pollution but some claim that they are also part of the solution. Philosopher John Passmore, for one, claims:

Solving the problem of pollution, then, means reducing the flow of substances or processes into places which are 'wrong'... Many of these substances are in the wrong place only as a result of scientific and technologic developments. The temptation therefore is to resist the view-as comparable with calling in the devil to exorcisethat we can solve our ecological problems only with the help of more science and more technology. But in the situation in which we now find ourselves, that is obviously the case. The scientists and technologies first drew our attention to the ecological problems which confront us, and without their aid we cannot hope to solve them, even if they, in turn cannot solve them by their own efforts [29].

However, Illich once again raises a red flag in regard to such a claim. For Illich, this is analogous to the self-reinforcing iatrogenic loop where "escalating destruction [is] generated by the pollution procedures used as anti-pollution devices"[30]. Illich's theory is based on the notion that Ecology, when constructed through technology, is no longer natural. Ecology, comparable to Health, can not be "designed on the engineering model... as if it were a commodity"[31]. Neither are mercantile items that may be taken to the market place without the additional price of also becoming a pollutant or a pathogen respectively. The argument stems from the view that the farther we get from the root, and the more we come to depend on technological and institutionalized solution, the farther we move away from the natural order where the true balance lies. This is the paradox recognized by many traditionalists and naturalists. As Emerson wrote:

To the senses and the unrenewed understanding, belongs a sort of instincitve belief in the absolute existence of nature. In their view, man an nature are indissolubly joined. Things are ultimates and they never look beyond their sphere. The presence of Reason mars this faith.[32]

I rose from my chair and thanked the woman whom I travelled to see. The sky was grey as I stepped outside. Namotis. She smiled peacefully as she looked over the water and my car thundered down the road toward East Bay. Keel ites na'tal. Kejidoo.

\section{REFERENCES}

1. Belmar R. Letter: Health Services in Chile. Lancet 1975; 1: 101

2. Blouin G. Weeds of the Woods: Small Trees and Shrubs of the Eastern Forest. Fredericton: Goose Lane, 1984.

3. Chiao RY, Kwiat PG, and Steinberg AM. Faster Than Light? Scientific American 1993; 269: 52-60.

4. Culpeper N. Complete Herbal. Hertfordshire: Omega Books, 1985.

5. Emerson RW. The Complete Writings. New York: William H. Wyse \& Company, 1929

6. Goodman LS and Gilman A. The Pharmacologic Basis of Therapeutics. Toronto: Collier Macmillan Canada, Limited, 1965.

7. Haywood JK. The Healing Herbs of the Caribbean and Beyond. Kingstown, Saint Vincent: 1993.

8. Illich I. Limits to Medicine. Middlesex: Penguin Books, 1976.

9. Kafatos M and Nadeau R. The Conscious Universe: Part \& Whole in Modern Physical Theory. New York: Springer-Verlag, Incorpo-
rated, 1990.

10. Katzung BG. Basic and Clinical Pharmacology, $6^{m}$ Edition. Norwalk: Appleton \& Lange, 1995.

11. Lacey L. MicMac Medicines: Remedies and Recollections. Halifax: Nimbus Publishing, 1993.

12. Medina E and Cruz-Coke R. Chilean Medicine Under Social Revolution. N Engl J Med 1976; 295: 193-197.

13. Passmore J. Man's Responsibility for Nature: Ecological Problems and Western Traditions. Surrey: Unwin Brothers, Limited, 1980.

14. Ritchason J. The Little Herb Encyclopedia. Pleasant Grove: Woodland Health Books, 1995.

15. Smith SC. St. John's Wort as a Treatment for Depression. Atlantic Psychopharmacology 1999; 2: 1-2.

16. Thomas $\mathrm{J}$ and Boyle $\mathrm{T}$. Teachings from the Longhouse. Toronto: Stoddart Publishing Company, Limited, 1994.

17. Thoreau HD. Walden. New York: Harper \& Row Publishers, 1965.

18. Waitzkin. The Social Origins of Illness: A Neglected History. Int $J$ Health Services $1981 ; 11: 77-103$

19. World Health Organization. List of Essential Drugs, Tenth List. Division of Drug Management Policies: http://www.who.int/dmp/
edl-10.htm.

\section{AUTHOR BIOGRAPHY}

Duncan Webster has a B.Sc. and a B.A. (Hon) from Mount Allison University, as well as a M.A. in Philosophy from UNB. He has worked as a teacher in Mexico, and in a medical lab in the West Indies. His previous work includes "The Medicine Wheel" for the Hannah Institute for the History of Medicine. 